\title{
BIOMETRY OF VETIVER GRASS CULTIVATED IN SOILS OF DIFFERENT TEXTURE CLASSES
}

\author{
Neife Santos Abraão ${ }^{1}$, Lilian Vilela Andrade Pinto ${ }^{1}$, Michender Werisson Motta Pereira ${ }^{2}$, \\ Fernando Yuri da Silva Reis ${ }^{1}$, Misael Silva Juliane ${ }^{1}$
}

\begin{abstract}
${ }^{1}$ Instituto Federal do Sul de Minas, Campus Inconfidentes. E-mail: neifesantos@gmail.com; lilian.vilela@ifsuldeminas.edu.br; fernando_ysr@hotmail.com; misael.julini@gmail.com

${ }^{2}$ Universidade Estadual de Campinas (UNICAMP). E-mail: michender.ambiental@ gmail.com
\end{abstract}

\begin{abstract}
The objective of this work was to analyze the biometric attributes of the vetiver grass in soils with clayey and clay loam texture. The experiment was made with double factorial design with casualized blocks, the first being two texture classes of soil (clay loam: 38\% clay; and clayey: $59 \%$ clay); and the second being six times of evaluation. The clump diameter at the soil height and the Dickson quality rate are not affected by the soil texture. The soil with clay loam texture had better development of the vetiver in height and number of tillers from 120 days of evaluations, with this soil type being recommended for the deployment of vetiver seedlings nurseries in contrast with clayey soils.
\end{abstract}

Keywords: Plants height, Chrysopogon zizanioides, tiller number, seedlings production

\section{BIOMETRIA DO CAPIM VETIVER CULTIVADO EM SOLOS \\ DE DIFERENTES CLASSES TEXTURAIS}

\section{RESUMO}

Objetivou-se analisar os atributos biométricos do capim vetiver em solos de textura argilosa e franco-argilosa. O experimento foi alocado em esquema fatorial duplo com blocos casualizados, sendo o primeiro fator: duas classes texturais do solo (franco- argilosa: 38\% de argila; e argilosa: 59\% de argila) e o segundo fator: seis tempos de avaliação. O diâmetro, a altura do solo das touceiras e o índice de qualidade de Dickson não são afetados pela textura solo. O solo com textura franco-argilosa promoveu melhor desenvolvimento do vetiver em altura e número de perfilhos a 
partir de 120 dias de avaliação, recomendando-se este tipo de solo para implantação de viveiros de mudas de vetiver em contrapartida a solos argilosos.

Palavras-chave: Altura de plantas, Chrysopogon zizanioides, número de perfilhos, produção de mudas

\section{INTRODUCTION}

The technological advances occurred in the last decades brought countless benefits to the human being, in contrast, it caused countless harms to the environment such as: soil degradation, deforestation, greenhouse gases emission, among others, such as the rupture of the dam in the city of Mariana, state of Minas Gerais, Brazil, in 2015.

The main activities responsible for the accelerated degradation of geomorphological aspects of the landscape are the human activities, like agriculture, mining, excavation, and construction of roads (INBAR et al., 1998); turning the exposed soil into susceptible to hydro superficial erosion, which is one of the main forms of soil losses in tropical environments and responsible for different environmental damages, due to the transport of soil particles, nutrients and organic matter (BERTONI \& LOMBARDI NETO, 1990) causing the soil depletion.

The vetiver grass (Chrysopogon zizanioides (L.) Roberty syn. Vetiveria zizanioides (L.) Nash) is a caespitose, perennial grass-like original from the South of Asia. It was heavily disseminated by the World Bank in the 1980s to assist in the erosion control and in the soil and water preservation in areas with few resources, especially in the developing countries (TRUONG et al., 2008).

The application of the vetiver has multiple functions of great importance in the mitigation of environmental damages, such as soil decompaction (COBRA et al, 2012), recovery of areas damaged by the urban solid waste disposal (RESENDE et al, 2015), the agricultural soils preservation, stabilization of inclined places, restoration of contaminated salt soils, and acting as effective barrier for the erosion and sediments control (TRUONG et al., 2008).

However, despite the great adaptability of the vetiver to the many soil conditions (TRUONG et al., 2008), it is known that the soil has great influence on the growth, development and plants production. The size of soil particles (granulometry) directly affects the root growth, because it modifies the deflection angle, as described by Bandara \& Fritton (1986). The quantity 
of water stored in the soil varies according to the texture, which results in the plants presenting different behaviors in relation to the adaptation mechanisms (CARLESSO, 1995).

As already noted by Truong et al. (2008), despite the great adaptability of the vetiver grass to the many soil conditions, there is a lack of information about the development of the species cultivated in different texture classes, and this information can be obtained by biometric analyzes of the plants.

The biometric analysis is very important for the attainment of growth data of a plant, since this data is evaluated through observation of the variation in any aspect, mainly morphological, according to the accumulation of material originated from the photosynthetic process (BENINCASA, 1988), and can be realized through the measurement of linear dimensions such as plant height, width and root volume, leaf area, number of tillers, among others.

Thus, the objective of this work was to analyze the biometric attributes of the vetiver grass in clayey texture soils and clay loam soils in order to indicate which texture class allows a better morphological development of the plant.

\section{MATERIAL AND METHODS}

The experiment was conducted at the Fazenda-Escola of the IFSULDEMINAS - Campus Inconfidentes, municipality of Inconfidentes, in the state of Minas Gerais, Brazil, in the period of September, 2014 to March, 2015.

According to the Köppen classification, the climate of the region is the humid-tropical (Cwa) with two well-defined seasons: rainy (October to March) and drought (April to September), with annual means of $1800 \mathrm{~mm}$ of rainfall and $19^{\circ} \mathrm{C}$ temperature. But, during the experiment realization from September of 2014 to March of 2015, the rainfall was $1009 \mathrm{~mm}$.

The vetiver seedlings in bare-roots, obtained by clump subdivision, were left with the roots immersed in water for 15 days in order to emit new roots and sprouts, thus selecting the most vigorous seedlings for the research. Altogether, 120 experimental units (bags) were cultivated, being 60 raffia-bags with capacity of 50 liters filled with clay loam-texture soil (38\% clay, 26\% silt and 36\% sand) and 60 raffia-bags with capacity of 50 liters filled with clayey-texture soil (59\% clay, $15 \%$ silt and $25 \%$ sand), according to the texture triangle of the Brazilian Society of Soil Sciences (SBCS). The soils with texture clay loam and clayey presented respectively 56,73\% and $46 \%$ of total porosity. There was not made any kind of correction or fertilization in both of the soils 
for the experiment implantation. The macronutrients values found in both of the soils were registered (Table 1).

Table 1. Chemical characteristics of clayey and clay loam soils.

\begin{tabular}{lllll}
\hline Soils & $\mathrm{P}\left(\mathrm{mg} / \mathrm{dm}^{3}\right)$ & $\mathrm{K}\left(\mathrm{mg} / \mathrm{dm}^{3}\right)$ & $\mathrm{Ca}\left(\mathrm{Cmol} / \mathrm{dm}^{3}\right)$ & $\mathrm{Mg}\left(\mathrm{Cmol} / \mathrm{dm}^{3}\right)$ \\
\hline Clay loam & 35,40 & 34,30 & 2,56 & 0,57 \\
\hline Clayey & 3,50 & 28,90 & 2,02 & 0,52 \\
\hline
\end{tabular}

In each raffia-bag there were planted 3 vetiver seedlings and after 10 days from the plantation it was conducted the visual qualitative selection of the seedlings, keeping only one seedling, with better development (height and tillering), in each raffia-bag.

The Dickson Quality Rate (IQD) is a rate that evaluates the viability of a seedling to be on the field. In this work, the rate was determined with an adapted form of the Dickson et al. (1960) equation; from the biometric attributes means obtained at 180 days considering the aerial part height (AP), the clump diameter at soil height (DIAM), the aerial part dry mass (MSPA), the roots dry mass (MSR), the total dry mass (MST), and the number of tillers (NP) using the equation:

$$
\text { Adapted } I Q D=\frac{\frac{M S T(g)}{N P}}{\left(\frac{A P(\mathrm{~cm})}{\left(\frac{D I A M(\mathrm{~mm})}{N P}\right)}\right)+\left(\frac{\frac{M S P A(\mathrm{~g})}{N P}}{\frac{M S R(\mathrm{~g})}{N P}}\right)}
$$

To do so, the experiment was assigned in double factorial design with casualized blocks ( 2 $x$ 6), the first factor being: two texture classes of the soil (clay loam and clayey); the second factor being: six times of evaluation (30, 60, 90, 120, 150, and 180 days after the plantation); and 10 blocks (experimental units).

The biometric attributes height of the plant (aerial part length) (AP) and number of tillers of each vetiver plant were evaluated every 30 days. The clump diameter at soil height (DIAM), the aerial part dry mass (MSPA) and the roots dry mass (MSR) were quantified at 180 days after the plantation.

Initially, there was determined the number of tillers of the plant still in raffia-bag, manually, counting the number of subdivisions (tillers) of the clump, pointing out that each tiller is a bare- 
root seedling. Following, the plants were carefully removed from the raffia-bags and wash on sieves for the disaggregation of the soil contained in the roots and the clump diameter was measured using a digital calliper. Immediately the plants were divided in aerial and root parts. The measurement of the height length of the plants (Figure 1B) was realized using a measuring tape. For the determination of the aerial part dry mass and root dry mass (Figure 1A), the aerial part and the vetiver roots were put, separately, in brown-paper-bags and taken to dry in greenhouse with forced air circulation at $65^{\circ} \mathrm{C}$ until it reaches constant weight.

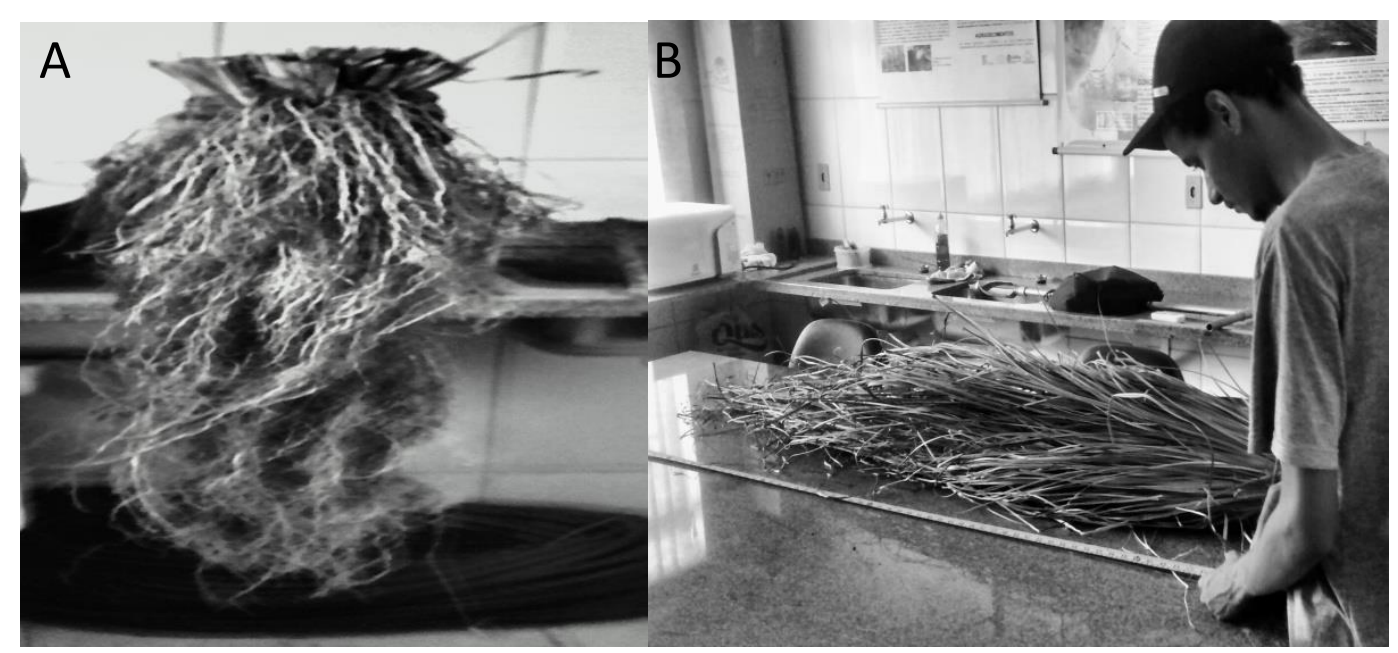

Figure 1. Vetiver seedlings: A) Vetiver root system; B) Measurement of the aerial part lenght. Photo: Authors.

The biometric data of the height (AP), root length, number of tillers, clump diameter at soil height (DIAM), aerial part dry mass (MSPA), roots dry mass (MSR), and total dry mass were tabulated and submitted to the variance analysis (ANOVA) following the factorial design of random blocks and its means were compared by the Scott-knott Test at 5\% of significance using the Sisvar (FERREIRA, 2011) software.

Pearson linear regression and correlation analysis at the level of $5 \%$ of significance was realized for the number of tillers with the development time, height with the development time, number of tillers with the height, and number of tillers with the clump diameter at soil height.

Afterwards, the obtained values were classified in weak, moderate and strong. According to Dancey \& Reidy (2006), a correlation is considered weak when it has correlation coefficients (r) from 0,10 to 0,30 ; moderate when it has a (r) from 0,40 to 0,60; and strong when the (r) is from 0,70 to 1 . 


\section{RESULTS AND DISCUSSION}

The vetiver height, as expected, presented crescent behavior during the evaluation period, in both soils. At 120, 150 and 180 days it was observed influence of the soil texture in the plant heights (Table 2).

Table 2. Medium height $(\mathrm{cm})$ of the vetiver aerial part in the soil with clay loam and clayey texture in different times of evaluation, Inconfidentes/MG, 2015.

\begin{tabular}{lllll}
\hline \multirow{2}{*}{$\begin{array}{l}\text { Time After Plantation } \\
(\text { days })\end{array}$} & \multicolumn{4}{c}{ Vetiver Medium Height $(\mathbf{c m})$} \\
\cline { 2 - 5 } & Clay loam Soil & \multicolumn{3}{c}{ Clayey Soil } \\
\hline $\mathbf{3 0}$ & Mean & $\mathbf{C V}(\boldsymbol{\%})$ & Mean & $\mathbf{C V}(\boldsymbol{\%})$ \\
\hline $\mathbf{6 0}$ & $72,33 \mathrm{Ae}$ & 13,10 & $63,00 \mathrm{Ad}$ & 17,46 \\
\hline $\mathbf{9 0}$ & $84,00 \mathrm{Ae}$ & 13,94 & $78,00 \mathrm{Ad}$ & 13,52 \\
\hline $\mathbf{1 2 0}$ & $105,33 \mathrm{Ad}$ & 14,29 & $97,66 \mathrm{Ac}$ & 14,92 \\
\hline $\mathbf{1 5 0}$ & $133,66 \mathrm{Ac}$ & 7,42 & $107,88 \mathrm{Bc}$ & 10,75 \\
\hline $\mathbf{1 8 0}$ & $170,55 \mathrm{Ab}$ & 8,55 & $142,22 \mathrm{Bb}$ & 12,20 \\
\hline & $190,4 \mathrm{Aa}$ & 7,45 & $172,6 \mathrm{Ba}$ & 7,99 \\
\hline
\end{tabular}

Means followed by lowercase in the column compare the data between times of evaluation and means followed by highercase in the line compare the data between the types of soil, not statistically differing between them, by the ScottKnott Test at level of 5\% significance when presents the same letter.

The plants height in the clay loam soil increased significantly from the 60 days of plantation in relation to the evaluated periods, reaching $190,4 \mathrm{~cm}$ at 180 days (6 months). Yet in the clayey soil, the vetiver height did not present significant difference between the times 30 and 60 days, and 90 and 120 days.

There were observed differences in the plants height between the types of soils from 120 days of development, in a form that in the clay loam soil were observed the highest values. At 180 days after the plantation there was obtained a medium plants height of $17,8 \mathrm{~cm}$ higher in the clay loam soil (Table 2).

Based on the literature, it was expected that higher results for vetiver height were obtained in the clayey soil, for theoretically having a higher cation-change capacity, higher water retention, lower permeability, higher specific surface in the particles, and consequently a higher fertility in natural conditions than the sandy soil (BUCKMAN \& BRADY, 1979). 
Among the literatures, Cox \& Lins (1984) can be mentioned for pointing out that the texture is one of the main quality and productivity indicators of the soils, and Santos et al. (2008) can be mentioned for affirming that the still current paradigm is that the Earth is said "productive" when the soil has a clayey texture.

According to Truong et al. (2008), the vetiver needs around 3 to 4 months for establishment. This can be evidenced in the results presented (Table 2), where the plants height was statistically equal from the first 60 days of evaluation for the same soil. However, it is worth highlighting that with only 30 days of evaluation the vetiver reached $27,47 \%$ and $24,91 \%$ of the mean total height observed at 180 days, respectively in the clay loam soil and clayey soil.

This result strengthens the importance of better use of vetiver as biomass for animal feeding, biomass, making handicrafts, mulching in agriculture areas, mulching for rural facilities, among others cited by Adams et al. (1999); Andrade et al. (2011); Manoel et al. (2013).

For Truong et al. (2008) and Teixeira et al. (2015), the vetiver grass can reach up from 1,5 $\mathrm{m}$ to $2,0 \mathrm{~m}$ high. The vetiver reaches a maximum of $1,5 \mathrm{~m}$ high. It is noted that with only 180 days of evaluation this research obtained promising results $(190,4 \mathrm{~cm}$ in the clay loam soil and 172,6 $\mathrm{cm}$ in the clayey soil) for overpassing these limits stablished in the literature, since that according to Truong et al. (2008) the plant reaches its maximum height around 12 months old.

The vetiver aerial part height has a positive linear correlation with the time of development of the plants, in other words, the height increases linearly in function of the time in both types of soil, presenting correlation coefficients $(r)$ and determination $\left(r^{2}\right)$ higher than 0,856 in both soils, significant at 5\% the significance (Figure 2A). In accordance with Dancey \& Reidy (2006), (r) values higher than 0,7 indicate strong correlation between the studied variables.

The analysis of the vetiver seedlings tillering indicated a significant increase of number of tillers/seedlings during 180 days of the experiment both in the clay loam texture soil and in the clayey texture soil (Table 3 ).

However, it is worth pointing out that in many moments were necessary more than 60 days for the statistical difference be observed. As related by Santos et al. (2011), the age of the plant (vetiver) interferes in the number of tillers. In the clay loam soil it was observed a higher tillering of the vetiver seedlings in relation to the clayey soil at $60,120,150$, and 180 days after the plantation (Table 3). 

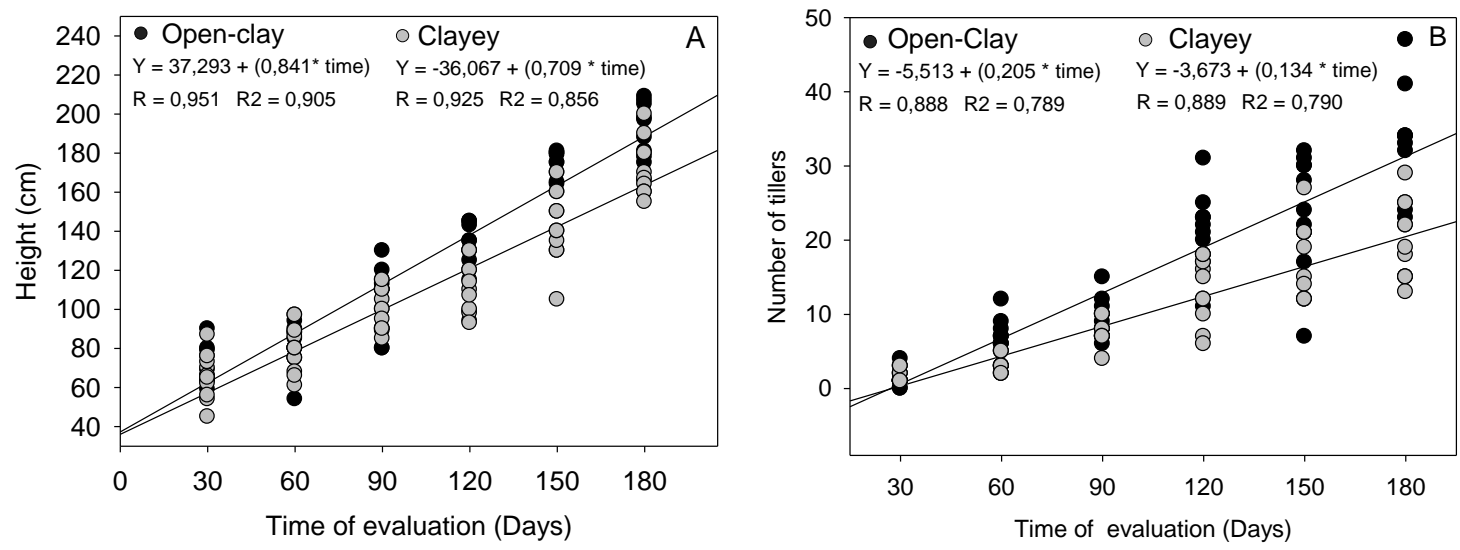

Figure 2. Graphic of linear dispersion of the vetiver grass development in clay loam and clayey soils: A) Height in $\mathrm{cm}$ and time of evaluation; B) Number of tillers and time of evaluation, Inconfidentes/MG, 2015.

Differences in the number of tillers at 168 days after the plantation in different texture classes and soils also were observed in experiment realized by Teixeira et al. (2015) where they evaluated the vetiver response to applications of phosphorus and limestone in three classes of different soils, thus obtaining higher values in the soils Haplic Cambisol (11 tillers) and Yellow Argisol (10,7 tillers) when compared to the Yellow Latosol (7,8 tillers). The number of tillers found by Teixeira et al. (2015) were lower than the numbers gathered by this research, which observed values higher than the authors' at 120 days (Table 3).

These results are important in the aspect of vetiver seedlings production (vegetative propagation by clump subdivision), indicating that soils with clay loam texture has potential for the production of a higher number of seedlings per planted than the clayey texture soils.

Blank et al. (2009) affirmed that through the increase of tillers per vetiver clump the number of plants removed from the field for the seedlings production will be lower, and consequently, more plants may have secondary uses, once the vetiver has been used for the most various functions such as stabilization of slopes (ANDRADE et al., 2011), soil decompaction (COBRA et al., 2012), nitrogen and phosphorus removal from domestic sewage (UCKER et al., 2012), animal feeding (MANOEL et al., 2013), recovery of areas damaged by urban solid wastes (RESENDE et al., 2015). 
Table 3. Number of tillers per vetiver plant in the soils with clay loam texture and clayey texture in different periods after the plantation, Inconfidentes/MG, 2015.

\begin{tabular}{lllll}
\hline \multirow{2}{*}{$\begin{array}{c}\text { Time } \\
\text { plantation (days) }\end{array}$} & \begin{tabular}{l} 
the \\
\cline { 2 - 5 }
\end{tabular} & \multicolumn{4}{c}{ Number of Tillers } \\
\hline & Mean & $\mathbf{C V}(\boldsymbol{\%})$ & Mean & $\mathbf{C V}(\boldsymbol{\%})$ \\
\hline $\mathbf{3 0}$ & $2 \mathrm{Ad}$ & 80,03 & $1 \mathrm{Ad}$ & 47,38 \\
\hline $\mathbf{6 0}$ & $7 \mathrm{Ac}$ & 26,02 & $3 \mathrm{Bd}$ & 33,67 \\
\hline $\mathbf{9 0}$ & $10 \mathrm{Ac}$ & 24,91 & $7 \mathrm{Ac}$ & 19,42 \\
\hline $\mathbf{1 2 0}$ & $21 \mathrm{Ab}$ & 23,73 & $13 \mathrm{Bb}$ & 31,92 \\
\hline $\mathbf{1 5 0}$ & $23 \mathrm{Ab}$ & 35,44 & $18 \mathrm{Ba}$ & 25,28 \\
\hline $\mathbf{1 8 0}$ & $32,7 \mathrm{Aa}$ & 21,79 & $19,3 \mathrm{Ba}$ & 25,28 \\
\hline
\end{tabular}

Means followed by lowercase letters in the line compare the data between times of evaluation and means followed by highercase letters in the line compare the data between the types of soil, not statistically differing between them, by the Scott-Knott Test at the level of 5\% of significance when present the same letter.

The number of vetiver tillers has positive linear correlation with time of development of the plants. In other words, the number of tillers increases linearly in function of the time in both types of soil, presenting correlation coefficients ( $\mathrm{r}$ ) and determination coefficients $\left(\mathrm{r}^{2}\right)$ higher than 0,790 in both of the soils (Figure 2B), having a strong correlation value, following values stablished by Dancey \& Reidy (2006).

Besides it, observing Figure $2 \mathrm{~B}$ it can be noted with more details the superiority of the tillering in the clay loam soil in relation to the results obtained with the clayey soil.

L'Huillier (1987) and Woodward (1998) reported that the lowest number of tillers of grasses may be related to the excess of shading in the plants, occurring, in many situations, the selfshading as consequence of the aerial part height.

In accord with what was found in the literature, it can be noted that the number of tillers in clay loam soil and clayey soil suffered interference in relation to the plants height. It was observed that the leaves of the biggest vetiver seedlings forms a curvature and consequently the shading of the plants. The vetiver presented a weak correlation between the number of tillers and the aerial part height, following values stablished by Dancey \& Reidy (2006), obtaining a (r) lower than 0,3 in both of the soils (clay loam and clayey) (Figure $3^{\mathrm{a}}$ ). 
Table 4. Results of the descriptive statistical analysis of the data of number of tillers of the vetiver diameter in soils with clay loam and clayey textures.

\begin{tabular}{lllll}
\hline Statistical Measure & \multicolumn{3}{l}{ Clay loam } & \multicolumn{2}{l}{ Clayey } \\
\cline { 2 - 5 } & Tillers & Diameter & Tillers & Diameter \\
\hline Mean & 33 & 101,3 & 19 & 98,9 \\
\hline Minimum & 23 & 80,45 & 13 & 82,685 \\
\hline Maximum & 47 & 130,59 & 29 & 120,63 \\
\hline Deviation & 8 & 13,5 & 5 & 12,8 \\
\hline CV $(\%)$ & 22,98 & 13,37 & 26,65 & 12,93 \\
\hline
\end{tabular}
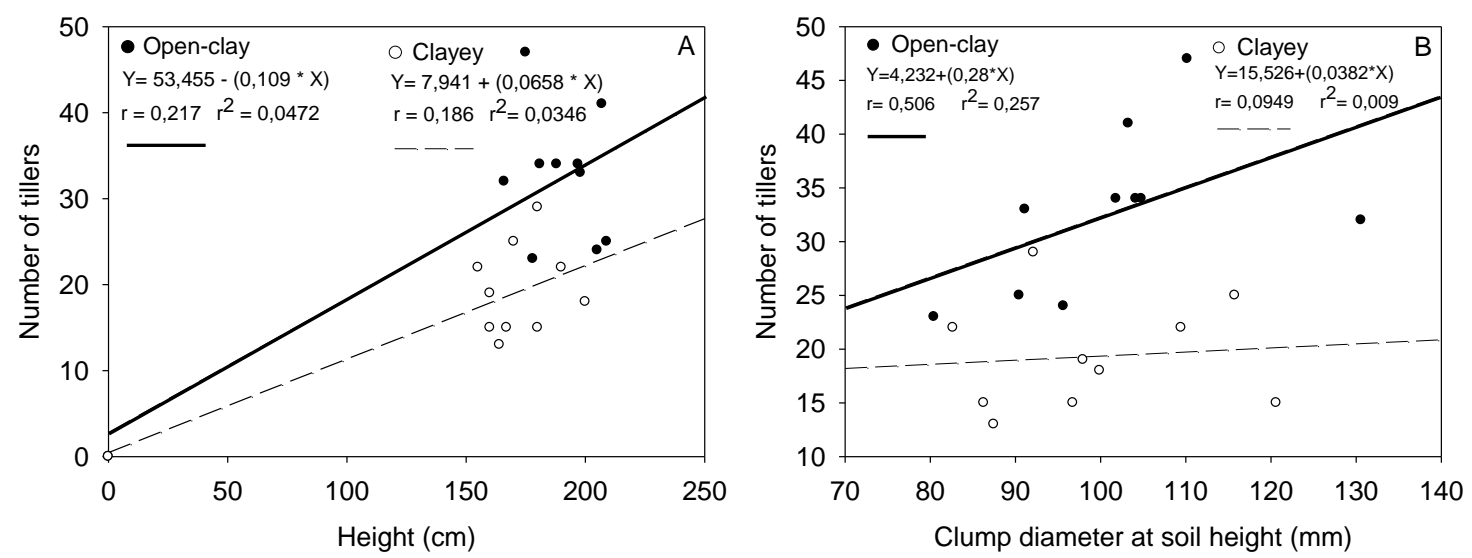

Figure 3. Graphic of linear correlation and regression of the vetiver grass in clay loam and clayey soils: A) Number of vetiver tillers and height; B) Number of tillers and clump diameter at soil height, Inconfidentes/MG, 2015.

The clump diameter at soil height of the vetiver grass at 180 days did not present statistical difference between the clay loam soil $(101,25 \mathrm{~mm})$ and clayey soil $(98,91 \mathrm{~mm})$ (Table 5). These results reinforce a species quality that is its good adaptation in different environment conditions, being a promising response for the vetiver use aiming at sediment retention, which, according to Truong et al. (2008), the higher the diameter at soil level, the higher the capacity of retention of the sediments by the plant.

In the work of Andrade et al. (2011), when evaluating the vetiver seedlings development in planted fields in three experimental blocks, being the soils of blocks 1 and 3 of medium texture and 
the soil of block 2 of clayey texture, also in the municipality of Inconfidentes/MG, it was observed that the clump diameter at soil height increased with time and obtained, at 180 days, a diameter mean of $30 \mathrm{~mm}$, and at 270 days a diameter mean of $80 \mathrm{~mm}$; values that are lower than the observed at 180 days in the present research $(101,25 \mathrm{~mm}$ and $98,91 \mathrm{~mm}$ in the soils with clay loam and clayey texture, respectively). A possible justification for this difference in the values is that the research developed by Andrade et al. (2011) was at a slope area with compacted soil, and the present research was developed in non-compacted soils conditioned in raffia-bags.

Evaluating the correlation between the number of tillers of the vetiver seedling with the clump diameter at soil height it was expected to observe a strong correlation between these variables. However, it was observed that in the clay loam soil there was a moderate correlation (r $=0,506$ ) according to the values stablished by Dancey \& Reidy (2006) and in the clayey soil it was not observed any correlation between the variables $(r=0,09)$ (Figure 3B and Table 4).

Table 5. Biometric attributes and adapted IQD of the vetiver grass at 180 days, Inconfidentes/MG, 2015. Being: PER = Number of tillers; DIAM = Diameter at soil height; MSPA = aerial part dry mass; MSR = root dry mass; $\mathrm{AP}=$ aerial part height; $\mathrm{MST}=$ total dry mass; IQDadap = Adapted Dickson Quality Rate.

\begin{tabular}{lllll}
\hline \multirow{2}{*}{ Attributes } & \multicolumn{2}{l}{ Values 180 days after plantation } & & \\
\cline { 2 - 5 } & Clay loam soil & & Clayey soil & \\
\hline Mean & CV (\%) & Mean & CV (\%) \\
\hline DIAM /PER & 3,19 & $\mathbf{1 2 , 6 8}$ & $\mathbf{9 8 , 9 1}$ & $\mathbf{1 2 , 2 7}$ \\
\hline MSPA /PER & 7,73 & 17,48 & 5,42 & 25,06 \\
\hline MSR/PER & 8,64 & 28,58 & 8,64 & 15,70 \\
\hline AP & 190,4 & 48,61 & 10,95 & 28,15 \\
\hline MST/PER & 16,37 & 7,46 & 172,6 & 7,99 \\
\hline IQDadap & $0,274 \mathrm{~B}$ & 34,65 & 19,59 & 18,7 \\
\hline
\end{tabular}

Means followed by the same letter in the column do not statistically differ between them by the Scott-Knott Test at the level of $5 \%$ of significance.

Regarding the Dickson Quality Rate (IQD), rate widely used in the literature for mono and dicotyledonous species of the Arecaceae family, it is appointed as being a good quality indicator of seedlings, for considering for its calculation the robustness (relation AP/DIAM) and balance of 
the phytomass distribution (relation MSPA/MSR) (FONSECA et al., 2002; CALDEIRA et al., 2005, 2007). However, IQD reference value for tillered seedlings was not found in the literature. Thus, in this research there was made an adaptation of this rate (IQDapadp), which was used as a form of comparing if the soils of different texture classes influence on the development of the seedlings by bare-roots of the species originated from the vetiver clumps. The IQDadap values obtained in the clay loam and clayey soils showed statistically difference at 180 days of evaluation (Table 5), however with values above 0,2, value preconized by Hunt (1990) as the minimum for the seedlings be considered with good final quality to be taken to the field. According to the author, the higher the IQD value, higher the quality of the seedling. The clayey soil had a higher value of IQDadap, demonstrating that the clumps that were produced in clayey soil had a quality higher than the clumps produced in clay loam soil.

\section{CONCLUSIONS}

The vetiver plants height and number of tillers (seedlings) are influenced by the soil texture, obtaining higher values in the clay loam texture soil.

The vetiver seedlings develop in soil with clay loam and clayey texture that are 180 days old present quality to be planted in the field, with the quality being influenced by the soil texture and better in the clayey soil.

The clump diameter at soil height that are 180 days old is not influenced by the soil texture.

Considering the biometric attributes evaluated, the soil with clay loam texture provides better development of the vetiver grass, with this soil being recommended for the implantation of seedlings nurseries and other productive areas with vetiver.

\section{ACKNOWLEDGEMENTS}

To IFSULDEMINAS for the equipment given by the notice 21/2013, to the Inconfidentes Campus for the equipment given by the notice 6/2013 and to FAPEMIG for the scientific initiation scholarship through the support from the researchers of the project APQ-01455-14.

\section{REFERENCES}

ADAMS R.P; DAFFORN M.R. 1999. DNA fingerprints (RAPDs) of the pantropical grass vetiver, Vetiveria zizanioides (L.) Nash (Graminea), reveal a single clone 'Sunshine' is widely utilized in erosion control. Assumption University Journal of Technology 2: 
173-180. Available at: http://www.vetiver.org/USA_dna.htm, Access in: September, 2015.

ANDRADE, L.L.; PINTO, L.V.A.; PEREIRA, M.W.M.; SOUZA, R.X. 2011. Avaliação da sobrevivência e do desenvolvimento de mudas de capim vetiver (Vetiveria zizanioides) em raízes nuas e produzidas em saquinhos de polietileno plantadas em diferentes espaçamentos.

Revista Agrogeoambiental, v. 3, p. 57-64. Available at: http://agrogeoambiental.ifsuldeminas.edu.br/index.php/Agrogeoambiental/article/viewFile/3 32/328, Access in: September, 2015

BANDARA, B.W.; FRITTON, D.D.1986. Directional response of corn roots to physical barriers. Plant and Soil, Dordrecht, v.96, p.359-368. Available at: http://link.springer.com/article/10.1007\%2FBF02375140\#page-1, Access in: September in 2015

BENINCASA, M.M.P. 1988. Análise de crescimento de plantas: noções básicas. Jaboticabal, FUNEP, 44p.

BERTONI, J.; LOMBARDI NETO, F.1990. Conservação do solo. São Paulo, Ícone, 392p.

BLANK, A.F.; PAULA, J.W.A.; ARRIGONI-BLANK, M.F.; MOREIRA, M.A. 2009. Utilização de paclobutrazol em vetiver na produção de mudas e seu efeito em plantas no campo. Horticultura Brasileira, 27:425-430. Available at: http://www.scielo.br/scielo.php?pid=S0102-05362009000400005\&script=sci_arttext, Access in: September, 2015

BUCKMAN, H.O.; BRADY, N.C. 1979. Natureza e propriedade dos solos. 5.ed. Rio de Janeiro, Freitas Bastos, 647p.

CALDEIRA, M.V.W.; MARCOLIN, M.; MORAES, E.; SCHAAD, S.S.2007. Influência do resíduo da indústria do algodão na formulação de substrato para produção de mudas de Schinusterebinthifolius Raddi, Archontophoenixalexandrae Wendl. et Drude e Archontophoenixcunninghamiana Wendl. et Drude. Ambiência, Curitiba, v. 3, n. 3, p. 311323.

CALDEIRA, M.V.W.; SPATHELF, P.; BARICHELLO, L.R.; VOGEL, H.L.M.; SCHUMACHER, M.V. 2005. Effect of different doses of vermicompost on the growth of Apuleialeiocarpa (Vog) Macbr. seedlings. Revista Acadêmica: Ciências Agrárias e Ambientais, Curitiba, v. 3, p. 11-17. Available at: http://www2.pucpr.br/reol/pb/index.php/academica?dd1=957\&dd99=view\&dd98=pb Access in: September, 2015

CARLESSO, R.1995.Absorção de água pelas plantas: água disponível versus extraível e a produtividade das culturas. Revista Ciência Rural, Santa Maria, V. 25, n. 1, p. 183-188. Available at: http://www.scielo.br/scielo.php?pid=S010384781995000100035\&script=sci_arttext, Access in: September. 2015

COBRA, R.L.; PINTO, L.V.A.; SOUZA, R.X.; PEREIRA, M.W.M.; PEREIRA, A.J. 2012. Resistência à penetração do solo de uma encosta: Efeitos de espaçamento de plantio e idade da gramínea Vetiver. Revista Agrogeoambiental, 4:1-9. Available at: http://agrogeoambiental.ifsuldeminas.edu.br/index.php/Agrogeoambiental/article/view/450, Access in: September, 2015

COX, F.R.; LINS, D.G. 1984.A phosphorus soil test interpretation for corn grown on acid soils varying in crystalline clay content. Communications Soil Science Plant Analysis., 15:14811491.

DANCEY, C.; REIDY, J. 2006. Estatística Sem Matemática para Psicologia: Usando SPSS para Windows. Porto Alegre, p.608 
DICKSON, A.; LEAF, A.L.; HOSNER, J.F. 1960.Quality appraisal of white spruce and white pine seedling stock in nurseries. Forestry Chronicle, v.36, p.10-13.

FERREIRA, D.F. 2011. SISVAR: A computer statistical analysis system. Ciência e Agrotecnologia, v. 35, p. 1039-1042. Available at: http://dx.doi.org/10.1590/S141370542011000600001 , Access in: May, 2018.

FONSECA, E.P.; VALÉRI, S.V.; MIGLIORANZA, É.; FONSECA, N.A.N.; COUTO, L. 2002. Padrão de qualidade de mudas de Trema micrantha (L.) Blume, produzidas sob diferentes períodos de sombreamento. Revista Árvore, Viçosa, v. 26, n. 4, p. 515-523, Jul./Aug. Available at: http://www.scielo.br/scielo.php?script=sci_arttext\&pid=S010067622002000400015, Access in: September, 2015

HUNT, G.A. 1990. Effect of styroblock design and coopertreatment on morfhology of conifer seedlings. In: Target Seedlings Syposium, Meeting of the Western Forest Nursery Associations, 1990, Roseburg. Proceedings.... Fort Collins: United States Department of Agriculture, Forest Service, p.218-222.

INBAR, M.; TAMIR, M.; WITTENBERG, L.1998. Runoff and erosion processes after a forest fire in Mount Carmel, a Mediterranean area. Geomorphology, v. 24, n. 1, p. 17-33. Available at: http://www.sciencedirect.com/science/article/pii/S0169555X97000986, Access in: September, 2015

L'HUILLER, P. J. 1987. Tiler appearance and death of lolium perenne in mixed swards grazed by dairy cattle at two stocking rates. New Zealand Journal of Agricultural Research. V.30, n.X,p. 15-22

MANOEL, D.S.; PINTO, L.V.A.; SOUZA, R.X.; OLIVEIRA NETO, O.F.; PEREIRA, M.W.M. 2013. Produção de biomassa da gramínea vetiver (Chrysopogon zizanioides (L.) Roberty) em diferentes espaçamentos após 420 dias do plantio. Revista Agrogeoambiental, Pouso Alegre, Edição Especial n. 1, p. 31-34, Aug. Available at: http://agrogeoambiental.ifsuldeminas.edu.br/index.php/Agrogeoambiental/article/view/567, Access in: September, 2015

RESENDE, L.A. de.; PINTO, L.V. A.; SANTOS, E.C.D.; SILVA, S. 2015.Crescimento e sobrevivência de espécies arbóreas em diferentes modelos de plantio na recuperação de área degradada por disposição de resíduos sólidos urbanos. Revista Árvore, Viçosa, v.39, n.1, p.147-157. Available at: http://www.scielo.br/pdf/rarv/v39n1/0100-6762-rarv-39-010147.pdf, Access in: September, 2015

SANTOS, F. C., NOVAIS, R.F.; NEVES, J.C.L.; FOLONI, J.M.; FILHO, M.R.A.; KER, J.C. 2008. Produtividade e aspectos nutricionais de plantas de soja cultivadas em solos de cerrado com diferentes texturas. Revista Brasileira de Ciência do Solo, Viçosa, v. 32, n. 5. Available at: http://www.scielo.br/scielo.php?script=sci_arttext\&pid=S0100-06832008000500023, Access in: September, 2015

SANTOS, M.E.R.; FONSECA, D.M. da.; PIMENTEL, R.M.; SILVA, G.P.; GOMES, V.M.; SILVA, S.P. da. 2011.Número e peso de perfilhos no pasto de capim-braquiária sob lotação contínua. Acta Scientiarum - Animal Sciences, v. 33, n. 2, p. 131-136. Available at: http://www.scielo.br/pdf/asas/v33n2/a03v33n2.pdf, Access in: September, 2015

TEIXEIRA, P.C.; MESQUITA, I.L.; MACEDO, S.T.; TEIXEIRA, W.G.; LIMA, W.A.A. 2015. Resposta de vetiver à aplicação de calcário e fósforo em três classes de solo. Revista Brasileira de Engenharia Agrícola e Ambiental, v. 19, n. 2, p. 99-105. Available at: http://www.scielo.br/scielo.php?script=sci_arttext\&pid=S1415-

43662015000200099\&lang=pt, Access in: September, 2015 
TRUONG, P.; VAN, T.T.; PINNERS, E. 2008. Sistema de Aplicação Vetiver: Manual de Referência Técnica, 2 ed. Tailândia: Rede Internacional de Vetiver., p. 116

UCKER, F.E.; ALMEIDA, R.A.; KEMERICH, P.D.C.2012. Remoção de nitrogênio e fósforo do esgoto sanitário em um sistema de alagados construídos utilizando o capim vetiver. Revista Ambiente e Água, Taubaté, v. 7, n. 3, p. 87-98. Available at: http://www.scielo.br/pdf/ambiagua/v7n3/v7n3a08.pdf, Access in: September, 2015

WOODWARD, S.J.R. 1998. Quantifying different causes of leaf and tiller death in grazed perennial ryegrass swards. New Zealand Journal of Agricultural Research. v. 41, p. 149159.

Received in: October 16, 2015

Accepted in: February 07, 2019 